Vol. 8 No.1 (Edisi) 2021

ISSN: 2355-7982|E-ISSN:2622-5115

http://jurnal.uinsu.ac.id/index.php/komunika

\title{
Peran Sultan Iskandar Muda dalam Pegembangan Islam dan Kesultanan Melayu di Sumatera Timur Mailin
}

Universitas Islam Negeri Sumatera Utara Medan Email.mmailin86@gmail.com

\begin{abstract}
This research is a historical study of the role of Sultan Iskandar Muda in the development of Islam and the Malay Sultanate in East Sumatra. The theory used in this research is role theory (Role Theory) which is a combination of theory, orientation, and scientific disciplines. Leadership theory and social role theory are also used in this study. The reason for using leadership theory and social role theory is because Sultan Iskandar Muda had an important position and role in Aceh and Sumatra, and was respected and respected by the community. This research approach uses a historical approach, with the techniques of collecting library data and documentation. Data analysis techniques using qualitative data analysis. The results showed that the role of Sultan Iskandar Muda (Sultan Aceh) was very large in the development of the Malay and Islamic regions in East Sumatra. Some of the kingdoms under the Aceh Sultanate were: the Deli Sultanate, the Asahan Sultanate, the Aru Kingdom, the Johor Kingdom, to several areas in East Sumatra. The conquest of the territory was accompanied by the spread of Islam in the East Sumatra region.
\end{abstract}

Keywords: Role; Development of Islam; Malay Sultanate

\begin{abstract}
Abstrak: Penelitian ini adalah penelitian sejarah peran Sultan Iskandar Muda dalam Pengembangan Islam dan Kesultanan Melayu di Sumatera Timur. Teori yang dipakai dalam penelitian ini adalah teori peran (Role Theory) yang merupakan perpaduan teori, orientasi, maupun disiplin ilmu. Teori Kepemimpinan dan teori peranan sosial juga di gunakan dalam penelitian ini. Alasan penggunaan teori kepemimpinan dan teori peranan sosial karena Sultan Iskandar Muda mempunyai kedudukan dan berperan penting di Aceh dan Sumatera, serta disegani dan dihormati oleh masyarakat. Pendekatan penelitian ini menggunakan pendekatan sejarah, dengan tehnik pengumpulan data kepustakaan dan dokumentasi. Tehnik analisis data menggunakan analisis data kualitatif. Hasil penelitian menunjukkan bahwa peran Sultan Iskandar Muda (Sultan Aceh) sangatlah besar dalam pengembangan wilayah Melayu dan Islam di Sumatera Timur. Beberapa kerajaan di bawah kekuasaan Kesultanan Aceh diantaranya: Kesultanan Deli, Kesultanan Asahan, Kerajaan Aru, Kerajaan Johor, sampai ke beberapa wilayah di Sumatera Timur. Penaklukan wilayah dibarengi dengan penyebaran Islam di wilayah Sumatera Timur.

Kata kunci: Peran; Pengembangan Islam, Kesultanan Melayu
\end{abstract}

\section{PENDAHULUAN}

Sejarah awal Islam masuk dan berkembang di wilayah Indonesia, banyak perdebatan panjang di kalangan ahli sejarah. Perdebatan seputar tempat asal, siapa pembawanya, dan waktu kedatangannya. Para pakar sejarah menuliskan beberapa teori terkait awal masuk dan berkembang Islam serta ajaran Islam di Nusantara. Namun terdapat tiga teori yang populer yaitu: Teori Makkah, Teori Gujarat dan Teori Persia (Azra, 2013). Ketiga teori tersebut menganalisis waktu masuknya ajaran Islam ke beberapa wilayah di Indonesia, berdasarkan bukti sejarah yang ada, diantaranya ke daerah Sumatera dan Jawa. Ketiga teori tersebut menjabarkan proses masuknya ajaran Islam sebagai berikut:

Pertama, Teori Gujarat, teori ini beranggapan bahwa Islam masuk ke Indonesia berasal dari Gujarat diperkirakan sekitar tahun ke 7 Hijriah / abad ke 13 M. Teori Gujarat ini mulai dikenal tahun 1883 oleh Snouck Hurgronje dan J Pijnapel dari Universitas Leiden (Drewes, 1968). Menurut teori ini, orang-orang Muslim Gujarat menyebarkan Islam ke Timur melalui jalur perdagangan, termasuk wilayah Indonesia. Pendapat ini senada dengan peneliti lainnya diantaranya: Umar Amir Husen dan Hoesein Djadjadiningrat, R.A. Kern, Dr. 
Gonda, dan lainnya. Selain itu, teori ini dikuatkan juga oleh ditemukannya makam batu nisan Sultan Samudera Pasai yaitu Malik as-Saleh tahun 1297 dengan corak Gujarat.

KeduaTeori Makkah yang diperkenalkan oleh salah seorang ulama Aceh, Haji Abdul Karim Amrullah (HAMKA). Teori ini memandang bahwa ajaran Islam masuk ke Indonesia langsung dari Makkah / Arab.pada sekitar abad pertama ijriah atau abad ke 7 Masehi. Teori ini menganggap bahwa daerah pertama yang menerima ajaran Islam adalah Aceh. Teri ini didasarkan kepada bukti keberadaan Kesultanan Pertama di Indonesia adalah Kesultanan Peureulak / Perlak (wilayah Aceh Timur provinsi Nangroe Aceh Darussalam ) berkuasa tahun $840-1292 \mathrm{M}$.

Ketiga, Teori Persia diperkenalkan oleh Prof. Aboebakar Aceh dan Hoesein Djajadiningrat sejarawan asal Banten. Teori ini menganggap bahwa ajaran Islam berkembang di Indonesia berasal dari Persia/ Iran. Teori ini dibuktikan dengan faham yang pertama sekali berkembang di Indonesia adalah faham Syiah. Disamping itu terdapat beberapa kesamaan tradisi dan budaya Persia dengan budaya masyaakat Indonesia, seperti peringatan 10 Muharram.

Berdasarkan sumber-sumber sejarah masuk dan berkembangnya Islam di Nusantara, para sarjana mengambil kesimpulan ${ }^{1}$ ahwa Islam pertama kali masuk melalui Negeri Aceh. Hal ini disimpulkan berdasarkan fakta bahwa Samudera Pasai berdiri sebagai Negara Islam pada akhir Abad ke 13 (Burhanuddin, 2017). Hal ini juga diperkuat dalam Hikayat Raja-raja Pasai yang menyatakan bahwa Malik-As-Saleh adalah raja pertama Samudera Pasai (Hill, 1960). Negeri Aceh dalam sejarah memiliki beberapa kerajaan terkemuka di belahan barat Nusantara (Burhanuddin, 2017). Kerajaan Aceh didirikan oleh Sultan Ali Mughayat Syah pada tahun 1496 M. Kerajaan ini berdiri di bekas wilayah kerajaan Lamuri (Dahlan, 2014). Kerajaan Aceh menundukkan dan menyatukan beberapa kerajaan di sekitarnya seperti Daya, pedir, Lidie, dan Nakur. Kerajaan Samudera Pasai juga berhasil ditaklukkan Aceh pada tahun 1524. Kejayaan Aceh sampai puncaknya pada masa pemerintahan Sultan Iskandar Muda perluasan wilayah sampai ke daerah Penang dan daerah Asahan di Sumatera Timur. Berdasarkan fakta sejarah ini, peneliti merasa tertarik melihat bagaimana peran Sultan dalam proses penyebaran ajaran Islam dan pengaruhnya terhadap beberapa kesultanan Melayu di Sumatera Timur.

\section{METODE}

Penelitian ini adalah penelitian sejarah menggunakan metode historiografi (Gottschalk, 1986). Metode sejarah disini adalah proses menguji dan menganalisa secara kritis rekaman dan jejak peninggalan masa lampau. Penelitian dengan metode ini dilakukan melalui tahapan - tahapan tertentu. Melalui metode ini peneliti ingin medeskripsikan peran seorang Sultan /pemimpin dalam sebuah kerajaan. Pneliti juga ingin melihat bagaimana peran Sultan Iskandar Muda dalam menyebarkan Islam di Sumatera Timur. Beberapa tahapan yang dilakukan dalam penelitian ini adalah sebagai berikut:

\section{Heuristik}

Tahapan pertama yang dilakukan adalah Tahapan heuristik untuk menghimpun jejak jejak sejarah masa lalu. Pada tahap pertama, peneliti mengumpulkan sumber terkait topik penelitian, serta mencari sumber-sumber tertulis yang dipercaya dan akurat tenatng sejarah yang berkaitan dengan Sultan Iskandar Muda yang terdapat di berbagai perpustakaan dan melalui internet yang berkaitan dengan Sultan Iskandar Muda dan perkembangan Islam di Sumatera Timur.

\footnotetext{
${ }^{1}$ Kesimpulan berdasarkan data yang terdapat pada batu nisan Malik as-Saleh tahun 1297, angka ini dianggap sebagai masa peralihan Samudera Pasai menjadi Negeri Islam. Hal ini dibandingkan dengan catatan Marco Polo yang menyatakan bahwa Samudera Pasai belum beralih ke Islam tahun 1292.
} 


\section{Kritik}

Tahap kedua adalah kritik terhadap sumber-sumber sejarah yang diperoleh dari berbagai literatur. Prosedur dilakukan dengan mengacu kepada keaslian sumber dan sumber yang faktual. Kelayakan terhadap ungkapan kebenaran sejarah, konsistensi sumber terhadap isi dan konten.

\section{Menguraikan fakta interpretasi}

Tahap selanjutnya adalah menguraikan fakta- fakta dan topik sebuah sejarah serta menjelaskan sesuai kondisi saat ini. Sebuah interpretasi bukanlah sebuah kesimpulan akhir, sehingga setiap generasi dapat memahami sejarah sesuai interpretasi masing-masing dengan alasan yang kuat dan dapat diterima. Peneliti dituntut bermain dengan imajinasi, dengan alasan bahwa bukti- bukti dan fakta sejarah tidak akan pernah lengkap dan sempurna selalu ada benang merah yang terputus, Tahapan ini merupakan hasil akhir dari kritik sebelumnya, sehingga akan menghasilkan kesimpulan dengan mengubungkan dengan bukti dan fakta yang ada kemudian akan menjadi sebuah pendapat yang logis dan dapat diterima sebagai sebuah sejarah .

\section{Historiografi}

Tahap ini merupakan tahap akhir sebuah penelitian sejarah. Tahap ini merupakan tahap mengambil sebuah kesimpulan berdasarkan dari hasil temuan dari tahapan sebelumnya, kemudian mengungkapkan, memaparkan hasil temuan berdasarrkan sumber sejarah yang diperoleh untuk disajikan secara tertulis .

\section{HASIL dan PEMBAHASAN Kerajaan- Kerajaan Islam}

Pembahasan berikut merupakan tahapan pertama dalam penelitian ini, yaitu heuristik, mengumpul jejak sejarah beberapa kerajaan Melayu yang ada di daerah aceh dan Sumatera bagian Timur, diantaranya adalah :

\section{Kerajaan Samudera Pasai}

Kerajaan Samudera pasai adalah kerajaan Islam pertama di Nusantara . ini berdasarkan catatn pelaut Italia Marco Polo yang pernah singgah di Samudera Pasai pada tahun 1292. Hal senada juga dituliskan oleh pengelana asal Maroko Ibnu Batutah yang penah singgah di Samudera Pasai sekitar tahun 1345 (Dahlan, 2014). Bukti lain terkait Samudera Pasai adalah terdapat batu nisan penguasa pertama Samudera Pasai, Sultan Malik Al- Saleh bertulis tahun 1297. Sejarah Samudera pasai berasal dari sebuah kerajaan bernama Samudera pada tahun 1270 M yang didirikan oleh Merah Silu dengan menyatukan sejumlah kerajaan kecil di wilayah Peurelak (Perlak). Merah Silu kemudian diIslamkan oleh nakhoda Ismail dan Fakir Muhammad pembawa Islam dari Madinah dan Malabar. Beliau berganti nama menjadi Malikussaleh atau malik al-Saleh. Kerajaan Samudera beralih menjadi Samudera Pasai pada tahun 1283 M. Kerajaan ini berpusat di sekitar Lhoksemawe Aceh bagian Utara .

\section{Kerajaan Aceh}

Kerajaan Aceh berada dalam wilayah Sumatera Utara dan berada di Bagian barat kepulauan Indonesia. Sebelah Barat Aceh terbentang lautan Hindia, disebelah Utara dan Timur berbatasan dengan selat Malaka, yang merupakan jalan lintas kapal-kapal pedagang dari berbagai negeri di Asia, Tiongkok dan India. Berdasarkan letak wilayah ini, tidak heran jika banyak bangsa asing masuk ke negeri ini. Kerajaan Aceh didirikan oleh Sultan Ali Mughayat Syah pada tahun 1469 M. pusat kerajaan berada di Lam Reh atau Aceh Besar. Kerajaan Aceh memiliki armada yang kuat sehingga dapat menundukkan dan menyatukan kerajaan di sekitarnya seperti Daya, Petir, Lidie, dan Nakur. Pada tahun 1524 Kerajaan Samudera Pasai berhasil di rebut Aceh. Aceh juga berhasil mengalahkan Portugis saat itu. Kejayaan Aceh maju berkembang pesat dan berberkuasa sampai pucak kejayaan Aceh ini pada masa kepemimpinan Sultan Iskandar Muda baik dalam bidang politik, agama, ekonomi, hukum, dan kebudayaan (Sufi, 1995). 


\section{Kerajaan Aru}

Kerajaan Haru atau Aru berada di wilayah pantai Timur Sumatera bagian Utara. Kerajaan Aru merupakan kerajaan besar dan penting yang pernah berdiri pada abad ke-13 yang dapat disetarakan dengan Malaka dan Samudera Pasai (Dahlan, 2014). Menurut Winstedt, pusat kerajaan Aru berada diwilayah kerajaan Deli sekarang. Sedangkan menurut Groeneveldt pusat kerajaan Aru berada di muara sungai Barumun (Padang Lawas). Menurut beberapa pendapat lain mengatakan bermuara di Sungai Wampu atau Teluk Aru.

Pada abad ke -16 kerajaan Aru termasuk salah satu kerajaan yang memiliki kekuatan besar di Selat Malaka, disamping Pasai. Aru kemudian menjalin hubungan baik dengan Portugal, dan dengan bantuan Portugal, Aru menyerbu Pasai pada tahun 1526. Kerajaan Aru kemudian di serang Kerajaan Aceh tahun 1539 dan tahun 1564. Aru dibantu oleh kerajaan Johor. Namun kerajaan Aru kembali diambil kerajaan Aceh masa pemerintahan Sultan Iskandar Muda tahun 1613. Nama Aru kemudian diganti dengan nama Deli. Agama Islam masuk ke kerajaan Aru menurut Hikayat Raja - raja Pasai berawal dari Nakhoda Ismail dan Fakir Muhammad yang mengenalkan Islam, kemudian mengislamkan raja Merah Silu, Raja Samudera Pasai pada abad ke -13 .

\section{Kerajaan Deli}

Kerajaan Deli didirikan oleh Tuanku panglima Gocah pahlawan pada tahun $1632^{2}$ dibawah kekuasan kerajaan Aceh. Sultan Iskandar Muda mengutus seorang laksamana Gocah Pahlawan sebagai panglima perang dalam peperangan kerajaan Aru dan Aceh, kerajaan haru berhasil ditaklukkan Aceh. Panglima Gocah Pahlawan kemudian ditempatkan sebagai pemimpin di daerah Deli sebagai Raja Kesultanan Deli pertama.(Dahlan, 2014). Kerajaan Deli kemudian memisahkan diri dari kerajaan Aceh pada tahun 1669, saat Aceh dipimpin oleh raja perempuan Ratu Taj Al-Alam Tsafiah Al-Din. Pemerintahan Kesultanan Deli pertama berada di Delitua, maka tidak heran banyak sebagian masyarakat menganggap nama Deli berasal dari nama daerah di India. Gocah Pahlawan dikenal berjasa mengalahkan 7 orang pengacau dari bangsa Turki. Berkat jasa jasa beliau inilah kemudian Sultan Aceh mengangkatnya menjadi Panglima perang. Beberapa kemenangan dalam peperangan berhasil diraih oleh Gocah Pahlawan, sampai peperangan terakhir dengan kerajaan Haru maka sangat wajarlah beliau diangkat menjadi wakil Aceh memerintah di Delitua.

Panglima Gocah Pahlawan kemudian meninggal dunia, kesultanan kemudian digantikan oleh putranya Panglima Perunggit. Ibukota kerajaan deli kemudian dipindahkan dari Percut ke daerah padang datar atau Medan Deli pada masa kepemimpinan Panglima Perunggit Kerajaan Deli memproklamirkan kemerdekaan dan memisahkan diri dari Kerajaan Aceh dan menjalin hubungan dengan Belanda di Malaka.

\section{Kerajaan Serdang}

Kerajaan Serdang merupakan salah satu kerajaan Islam berpusat di Sumatera Utara. Kerajaan Serdang termasuk salah satu kerajaan dibawah kekuasaan Kerajaan Aceh masa Sultan Iskandar Muda. Kesultanan Serdang berdiri tahun 1723 pecahan dari kesultanan Deli didirikan oleh keturunan kesultanan Deli, yaitu: Tuanku Umar Johan Alam Shah, sebagai raja pertama Kesultanan Serdang. Kesultanan Serdang mencapai masa kejayaan nya pada masa pemerintahan Sultan Thaf Sinar Basyar Shah, tahun 1822-1851. Kesultanan Serdang berdiri selama lebih kurang dua abad mulai tahun 1723 - 1946. Pada masa kurun waktu tersebut, Kerajaan Srdang di pimpin 5 orang Sultan . Sultan Serdang I Tuanku Umar Johan Pahlawan Alam Syah (1723-1782), Sultan ke II Tuanku Sultan Ainan Johan Alma Syah (1782-1822) selanjutnya Sultan Thaf Sinar Basyar Syah (1822-1851), selanjutnya Sultan Basyaruddin Syaiful Alam Syah(1851-1879), dan terakhir Sultan Sulaiman Syariful Alam Syah (18791946) (Dahlan, 2014). Wilayah kesultanan Serdang mulai Batang Kuis, Bedagai, Percut,

${ }^{2}$ Menurut Hikayat Deli, Gocah Pahlawan berasal dari Delhi (India), nama asli nya adalah Muhammad Deli Khan masih keturunan raja India yang terdampar di Pasai. 
Senembah, Araskabu, dan Perbaungan. Saat ini seluruh wilayah ini menjadi bagian dari wilayah Deli Serdang (Kesultanan Serdang, 2020).

\section{Kerajaan Langkat}

Kerajaan Langkat adalah kesultanan yang berada di wilayah kabupaten Langkat. Kerajaan Langkat terkenal sebagai wilayah makmur, karena terdaapat perkebunan karet dan ditemukannya cadangan minyak di wilyah Pangkalan Brandan. Menurut sejarah, kesultanan Langkat termasuk salahsatu Kerajaan Melayu tertua di Sumatera Timur. Sejarah Kesultanan Langkat berasal dari salah sdeorang petinggi Kerajaan Aru/Haru bernama Dewa Shahdan. Dewa Shahdan dikisahkan berhasil menyelamatkan diri dari serangan kerajaan Aceh, dan kemudian mendirikan kerajaan sekitar tahun 1500 -1580 M. Kerajaan ini yang kemudian menjadi Kesultanan langkat. Kesultanan Langkat termasuk daerah dibawah kekuasaan Kesultanan Aceh sampai awal abad ke 19 (Zuhdi, 2013).

\section{Kerajaan Asahan}

Kesultanan Melayu Asahan didirikan oleh Sultan Iskandar Muda melalui penobatan putra nya Tuanku Sultan Abdul Jalil sebagai Sultan Pertama Negeri Asahan tahun 1630 saat ini menjadi Kota Tanungbalai Asahan (Arsjad, 1933). Sejarah kesultanan Asahan ini tidak terlepas dari sejarah perjalanan Sultan Aceh, Sultan Iskandar Muda ke Johor dan Malaka tahun 1612. Sultan dan rombongan dalam perjalanan beristirahat di Kawasan sebuah hulu sungai sekarang dinamakan Asahan. Perjalanan Sultan beserta rombongan dilanjutkan ke sebuah "Tanjung" (pertemuan antara sungaiAsahan dengan Sungai Silau), di tempat ini Sultan bertemu dengan Raja Simargolang. Rombongan atas perintah Sultan Iskandar Muda mendirikan sebuah pelataran (Balai) sebagai tempat duduk peristirahatan sementara yang kemudian berkembang menjadi sebuah perkampungan, saat ini Kota Tanjungbalai.

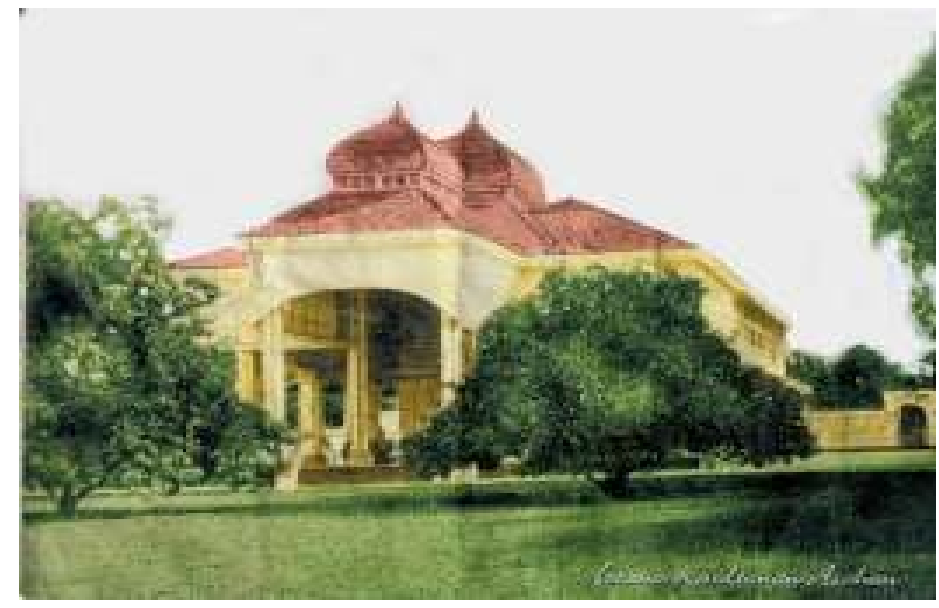

Gambar: 1

Istana KRIS (kota Raja Indera Sakti) di Tanjungbalai 1925

Kesutanan Asahan adalah Kerajaan Melayu dibawah perlindungan Kerajaan Aceh hingga abad ke -19. Hal ini wajar, dikarenakan Sultan pertama Asahan adalah putra Sultan Iskandar Muda dari perkawinan Sultan dengan Putri Siti Ungu. Sejak penobatan Kesultanan Asahan pertama tahun 1630 - sekarang, Asahan memiliki 13 orang Sultan.

\section{Kerajaan Pinang Awan (Kota Pinang)}

Kerajaan kota Pinang berdiri tahun 1630, saat ini lebih dikenal dengan sebutan kabupten Labuhan Batu Selatan, Sumatera Utara. Kesultanan Kota Pinang awalnya bernama Kesultanan Pinang Awan yang didirikan oleh Batara Sinomba, putra Sultan Alamsyah Syaifuddin dari kerajaan Pagaruyung. 


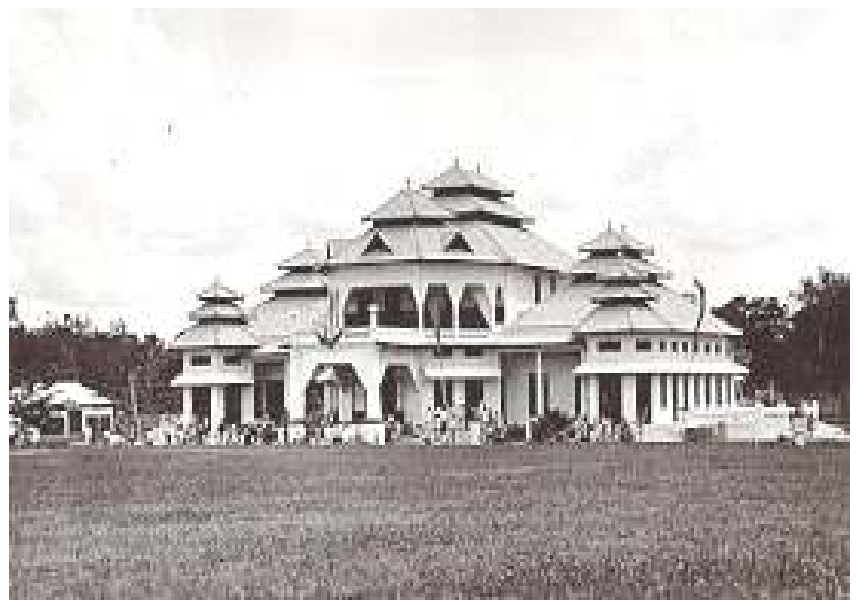

Gambar 2; Istana Kota Pinang

Menurut riwayat/silsilah kerajaan Melayu Pinang Awan, pendirinya adalah seorang Pemuda yang berasal dari kerajaan Minangkabau dimasa pemerintahan Raja Alamsyah Syaifuddin raja Pagaruyung, keturunan dari Raja Adithyawarman yang memerintah pada Abad ke XV M. Walau pun Raja Pinang Awan berasal dari Pagaruyung Minangkabau tetapi hubungan dengan Pagaruyung putus sama sekali, adat istidat Minangkabau tidak dipakai didaerah ini, meraka memakai adat istiadat Melayu dan Puak Melayu. Batara Sinomba beristrikan Putri Langgageni dan bermakam di Hotang Momo ( Marhum Hutang Momo ) Adapun Batara Sinomba mempunyai Putra tiga Orang Anak salah satu diantara Putranya yang bernama : Sutan Mangkuto Alam gelar Marhom Mangkat dijambu menjadi raja di Air Merah ( Panai ) beristrikan anak dari Raja Angkola, memiliki lima Orang anak, salah satunya adalah putri Siti Oengoe. Putri Siti Oengoe ( Siti Oenai ) dan Siti Maja di bawa ke Aceh yang dikemudian putri Siti Oengoe dikawinkan dengan Sultan Iskandar Muda (Said, 2007).

\section{Kritik Sumber}

Sumber-sumber terkait sejarah Sultan Iskandar Muda dan kerajaan Aceh banyak terdapat di beberapa rujukan baik melalui buku sejarah dan sumber internet/website. Walaupun terdapat beberapa perbedaan tahun dan nama namun tidak terlalu merubah bukti sejarah terkait Sultan Iskandar Muda dan Kerajaan Aceh. Peneliti memiliki sumber sejarah yang akurat serta bukti sejarah sehingga sehingga penulisan sejarah daat diselasaikan.

\section{Analisis Fakta Sejarah}

Berdasarkan penelusuran dari beberapa sumber dan bukti sejarah terkait profil dan kepemimpinan Sultan Iskandar Muda, bahwa keberhasilan sebuah kerajaan tidak lepas dari peran seorang Pemimpin. Kerajaan Aceh memiliki kekuatan dan kejayaan Aceh mulai awal berdirinya hingga pada masa pemerintahan Sultan Iskandar Muda tidak terlepas dari keahlian seorang Sultan dalam mengatur serta menyusun strategi politik kenegaraan dalam memakmurkan rakyatnya dan memperluas wilayah kerajaan. Kerajaan Aceh yang didirikan oleh Sultan Ali Mughayat Syah tahun 1496 hingga kepemimpinan sultan Iskandar Muda berhasil menguasai beberapa wilayah dan menyatukan beberapa kerajaan di sekitar wilayahnya. Kerajaan Samudera Pasai dan Aru kemudian berhasil ditaklukkan Aceh.

Pada masa kepemimpinan Sultan Iskandar Muda, kerajaan Aceh memiliki kekuatan armada angkatan laut yang sangat tangguh sehingga mampu dengan mudah mengontrol wilayah perdagangan barat Laut dan ekspansi ke luar wilayah Aceh. Sultan kemudian melakukan kerjasama dengan Kerajaan Turki dan Kerajaan Inggris. Kerjasama ini dilakukan untuk mendapatkan bantuan persenjataan dan ahli-ahli militer. Walaupun demikian, Sultan 
tetap memperkuat dan memberdayakan kekuatan pasukan yang dimiliki Kerajaan Aceh saat itu. Kontrol dan kendali kerajaan dapat terlaksana dengan baik dan lancar di semua bidang, terutama di pantai barat Sumatera, pantai timur, serta di bagian Selatan (Asahan). Penaklukan bahkan sampai ke Penang, di pantai timur Semenanjung Melayu. Peran dan kepiawaian Sultan Iskandar Muda dalam mengembangkan dan menguasai beberapa kesultanan Melayu di Sumatera Timur serta menyebarkan ajaran agama Islam terlihat di sini. Berikut beberapa Kerajaan Melayu Di Sumatera Timur yang memiliki hubungan langsung dengan Kerajaan Aceh. Diantara beberapa kerajaan tersebut adalah : Kerajaan Aru, Kerajaan Deli, Kerajaan Asahan.

\section{KESIMPULAN}

Berdasarkan hasil penelitian yang dilakukan, maka dapat disimpulkan bahwa seorang Sultan/pemimpin sangat besar perannya dalam mengembangkan serta memakmurkan sebuah wilayah. Sultan Iskandar muda merupakan salah satu sultan/pemimpin yang memiliki peran yang sangat besar dalam memperluas wilayah kekuasaan Negeri Aceh dan mengembangkan ajaran Islam di Nusantara mulai Negeri Aceh sampai ke Sumatera Timur. Kejayaan Sultan Iskandar Muda dalam memimpin Aceh menjadi sebuah sejarah Islam yang membanggakan dan menjadi inspirasi bagi pemuda dan pemimpin -pemimpin masa depan.

\section{DAFTAR RUJUKAN}

Arsjad, M. (1933). Thabal Mahkota Negeri Asahan.

Azra, A. (2013). Jaringan Ulama Timur Tengah dan Kepulauan Nusantara Abad XVII \& XVIII. Kencana.

Burhanuddin, J. (2017). Islam dalam Arus Sejarah Indonesia. Kencana.

Dahlan, A. (2014). Sejarah Melayu. Kepustakaan Populer Gramedia.

Drewes, G. W. J. (1968). New Light on the Coming of Islam to Indonesia? Kitlv. http//www.kitlv-journals.nl

Gottschalk, L. (1986). Mengerti Sejarah. UI Press.

Hill, A. . (1960). Hikayat Raja-raja Pasai. Journal of the Malayan Branch Royal Asiatic Sociaty, XXXIII(2).

Kesultanan Serdang. (2020). https://id.wikipedia.org/wiki/Kesultanan_Serdang

Said, M. (2007). Aceh Sepanjang Abad. Harian Waspada.

Sufi, R. (1995). Pahlawan Nasional Sultan Iskandar Muda. Proyek Inventarisasi dan Dokumentasi Sejarah Nasional.

Zuhdi, S. (2013). Langkat dalam Kilatan Selintas Jejak Sejarah dan Peradaban. 